\title{
A Bicultural Dream in Aotearoa New Zealand: (De)Colonising Shakespeare?
}

\author{
'How easy is a bush supposed a bear!' (A Midsummer \\ Night's Dream V.i.23)
}

\section{Prologue}

This essay came into being as a way of 'thinking out loud' about the stirring of traditions - Shakespearean and Māori into an idealised spectacle of reconciliation that belies its own theatrical, historical and social foundations. ${ }^{1}$ When I was coming up as a theatre director in the USA, the production of Shakespearean theatre was aspirational, requiring rigorous training in textual analysis as well as physical and vocal grace, as was evident in the shows I still remember from school and other trips to the Oregon Shakespeare Festival in the 1970s and 1980s. Whether on professional stages, in schools and universities, or in community theatres, Shakespeare's plays were produced, often explicitly, to uplift us - whoever 'we' were - from our otherwise more mundane theatrical and social circumstances and preoccupations. The Pop-up Globe Theatre in Auckland, New Zealand, is a product of such aspirations. It promises an encounter with erudition made accessible

\footnotetext{
1 This article has been adapted from a paper titled 'None so blind . . . (De)Colonising Shakespeare?' that was presented at the Native American and Indigenous Studies Association (NAISA) conference (Waikato University, 27 June 2019). My thanks again to Brenda Machosky (University of Hawai i) for organising the 'Indigenous Shakespeare' panel and inviting me to contribute. Thanks also to Natascha Diaz Cardona for coming along to the show, for the conversation that followed and for reading this paper in its early stages.
}

Sharon Mazer is Associate Professor in Theatre \& Performance Studies at Auckland University of Technology. 
through low jokes and entertaining shenanigans. ${ }^{2}$ And it certainly delivers.

Shakespeare's plays are great because of their universalism, so we continue to be told. But in fact they were first and foremost products of their place and time, playing on and revealing the strata of class, race and gender in ways that were affirmational to their audiences, acts of reification rather than radicalisation. So too the Pop-up Globe's bicultural production of A Midsummer Night's Dream $(2017 / 2018) \cdot{ }^{3}$ In finding common ground with the groundlings, it also necessarily plays into rather than against stereotypes, and toward rather than against affirmation of the status quo. The Pop-up Globe's success is that it mixes entertainment with education. Its appeal is to teachers, students and their parents - a spoonful of sugar approach to an otherwise starchy run-in with high culture. But what is it they're teaching?

\section{A Bicultural Dream}

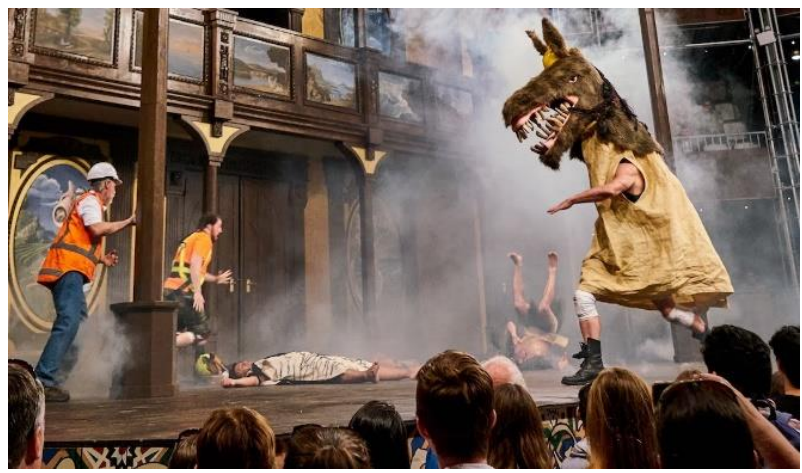

Titania in her bower ${ }^{4}$

2 See the Pop-up Globe's website:

https://popupglobe.co.nz/about/welcome/.

${ }^{3}$ For a description of the performance, see the $N Z$ Herald review by Dione Joseph (2017).

${ }^{4}$ All images have been downloaded from the Pop-up Globe's $A$ Midsummer Night's Dream promotional website:

https://popupglobe.com.au/shows/midsummer-nights-dream/. 
We're midway through a performance of A Midsummer Night's Dream. Titania is asleep in her bower. She is lying on the bare stage of the Pop-up Globe Theatre in Auckland, New Zealand, just right of centre, her feet to the audience, her head a metre or so from the inner below. She is wearing a korowai a feathered cloak that is traditional to Māori culture as a marker of high status. (Although I'm pretty sure that's not supposed to be on the stage floor in that way.) She is actually a he. This is an all-male cast, in keeping, the director (Dr Miles Gregory) claims with the Pop-up Globe's aim to give audiences an 'authentic' experience in this simulation of Shakespeare's theatre. (Although I'm certain that the boy actresses of Shakespeare's time were significantly younger, much prettier and far more at ease with the homoerotics of their performances.) Because this is Aotearoa New Zealand, however, this European, high cultural ambition has been tempered with biculturalism. Three key roles Theseus/Oberon, Hippolyta/Titania, and Puck - along with a number of the fairies are being played by Māori actors wearing approximations of pre-contact native dress, adorned with feathers and carvings, waving patu and rākau. Large passages of text are uttered in te reo Māori. (Although I suspect the reo is not a direct translation from the original, and to my ear it sounds a bit dodgy - a suspicion confirmed by a fluent friend afterward.) A number of haka are performed, including by the full company to Elizabethan-esque music during the curtain call.

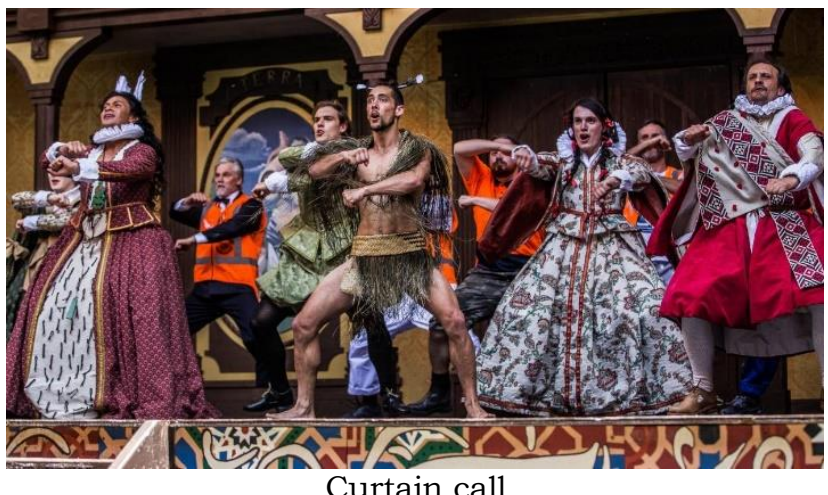


The Pop-up Globe's audience is enthusiastic. I'm less-so. But then, this isn't the first time I've felt uneasy about the effects of what's often called 'colour-blind' or 'non-traditional' casting. I recall a production of A Midsummer Night's Dream, set in Brazil, at the Public Theatre in New York City almost thirty years ago, and one of Othello, set in colonial New Zealand, featuring prominent Māori theatre artist Jim Moriarty some twenty years ago at the Court Theatre in Christchurch. As I watch this Dream, they resurface in my consciousness, like the return of the repressed and a chastisement. I'm too resistant to seeing a performance the way the company wants me to see it. All I see, again, is how the most well-intentional attempts to integrate or 'decolonise' the stage can go awry, and how difficult it can be, with all this good cheer, to see what we in fact see being performed.

This article interrogates two apparently contradictory assumptions about what it means to include identifiably Māori actors and performance practices in productions of Shakespeare's plays. During the colonial period in Aotearoa New Zealand as elsewhere, performances of Shakespeare's plays served as a platform for the identity maintenance of British subjects, a way of sustaining an idea(l) of themselves as civilised against the backdrop of what they saw as a savage land and people. In recent years, however, it has become an article of faith that following the paradigm of colour-blind and non-traditional casting practices here as elsewhere can serve to decolonise the stage in service of a more progressive, bicultural social agenda. ${ }^{5}$ While there has been some academic discussion of Te Tangata Whai Rawa o Weniti, The Māori Merchant of Venice, 6 here I want to look at a number of Pākehā-centric productions: focusing primarily on $A$ Midsummer Night's Dream (Pop-up Globe Theatre, Auckland, 2017/2018), with a side-glance at Othello starring Jim Moriarty in the title role (Court Theatre, Christchurch, 2001).

\footnotetext{
5 See, for example, Christopher Balme's now-canonical Decolonizing the Stage: Theatrical Syncretism and Post-Colonial Drama (1999) and also Rustom Bharucha, Theatre and the World: Performance and the Politics of Culture (1993). For differing perspectives on colour-blind, non-traditional and other diverse casting practices, see, for example: Young, 2013; Thomas, 2014; Rogers \& Thorpe, 2014; Thompson, 2011; Newman, 1989; Deboo, 1990; and Schultz, 1991.

6 See McDougall, 2002.
} 
How might the performance of Māori in Shakespearean productions be seen as ambi-valent: simultaneously challenging and reifying what are still conventional, often virulent, not quite post-colonial, characterisations of the relationship between Māori and Pākehā New Zealanders?

To return to Titania asleep in her bower. If you look sharp, you can see her in the production's promotional clip. ${ }^{7}$ It looks like such fun. From where we were sitting, up near the gods, we could see how much the audience loved it.

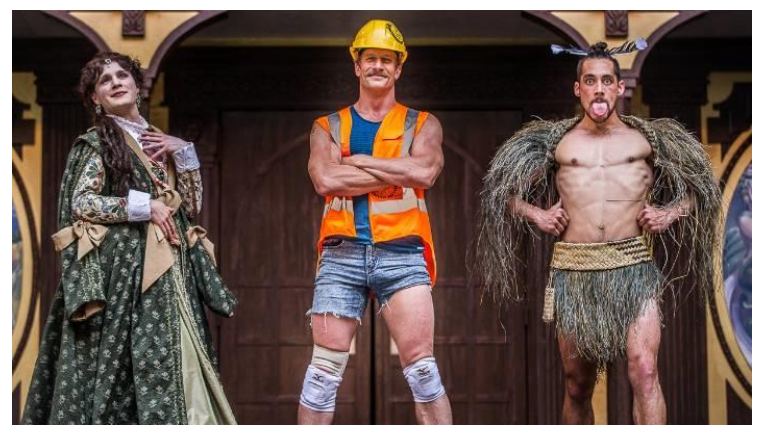

Elizabethan (wo)man, tradie \& Māori

It's palpably utopian, I think: this vision of Pākehā and Māori men, in Shakespearean male and female drag, dressed as tradies and as pre-colonial natives, dancing together somewhere on the continuum from the Elizabethan to the haka. That they are all men signals a kind of unity: an oldboys, old-school universality as uncomplicated by gender and sexuality as it is by the twin encroachments of capitalism and globalisation, and not at all tainted by the residue of colonisation. ${ }^{8}$ I feel cranky for being critical in the face of such good cheer. But still ...

7 'Auckland Season 3: A Midsummer Night's Dream': https://www.youtube.com/watch?v=fE2HgT4bj9U.

${ }^{8}$ I am deferring a consideration of the queerness of this production and its problematic strategies for displacing homophobic anxiety onto the Māori 'fairies'. The controversy surrounding last year's announcement that the Pop-up Globe's production of The Taming of the Shrew would feature an all-male cast while somehow also taking a 


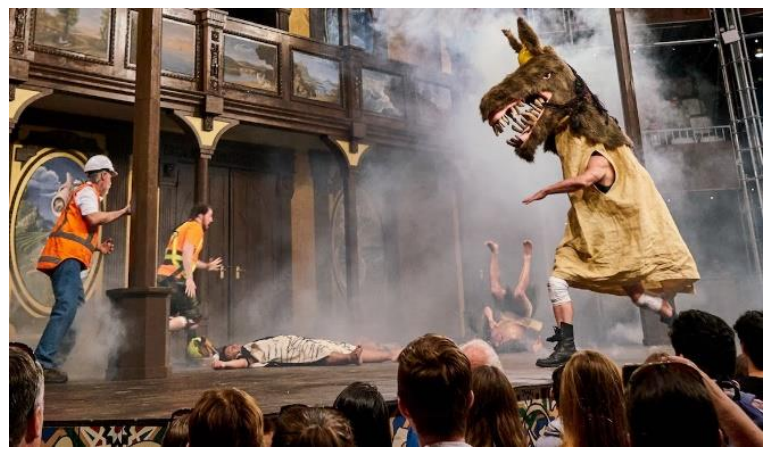

There's a lot going on here. Bottom is chasing his friends, who have been frightened by his rather fierce appearance. Puck is turning a summersault. Titania remains supine. She will lie still for a very long time - I guessed 30 minutes - as the company, unseeing, catapults and cavorts around the stage. They shout and leap over her. At one point, near the end of her slumber, one of the rustics actually sits on her as though she's a fallen tree or a stone, part of nature. She's there, but not there.

I've been stuck on this image for over a year now. Part of my response is a theatre director's exasperation. Could they not have parked her upstage to one side, as most productions do, or even in the inner-above? Could they not have given her some kind of shelter - at least some semblance of a 'bower' as the script indicates? It's not as if they didn't have lots of props - including this phallically augmented 'Wall'. is more than the present article can bear. (See Desmarais, 2018). 


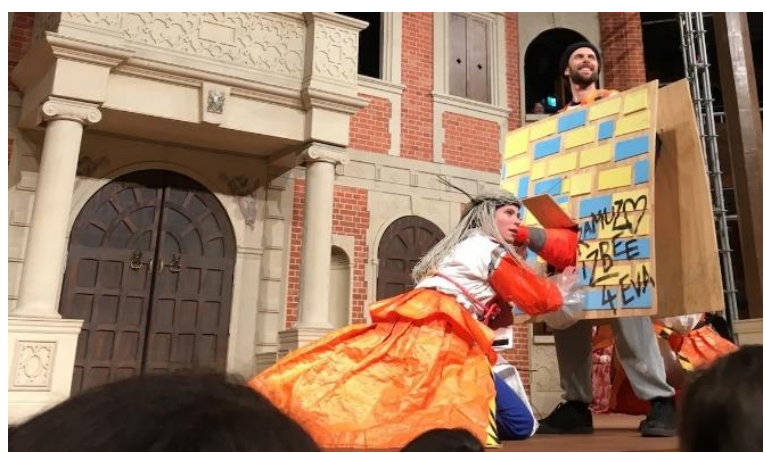

Pyramus and Thisby

A few branches would not have been out of place and would have given us a sense of Titania being in place, in her 'close and consecrated bower' (Dream III.ii.7) as Shakespeare's text indicates. The production was impeccably (if cavalierly) choreographed, so I have to see the placement of Titania - the (Māori) queen - as intentional, albeit not necessarily meaningful in the way intended. Again, I look.

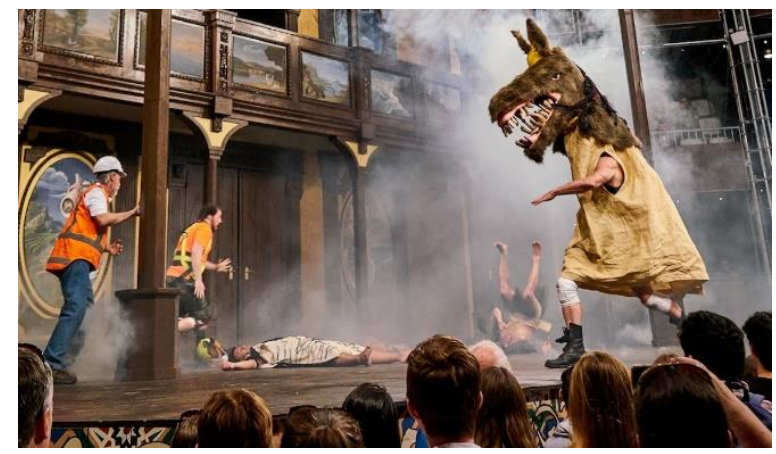

Titania is invisible to everyone. To the aristocratic, Pākehā lovers. To the fair dinkum Pākehā tradies - the Kiwi blokes. It's the spitting image of terra nullius - the empty land of the coloniser's fantasy. And what of (the Māori) Puck's shenanigans? He knows she's there, but pretends she isn't. The actors count on us to laugh along with them as they carry 
on. We are, like them, directed to overlook her, this (Māori) queen, as she remains motionless. And for the longest time, even we in the audience are more mobile, more agentic, than she appears to be. Is this what it is to be complicit in acts of colonisation?

\section{None so blind ...}

There was a time, not so long ago, when non-traditional and colour-blind casting practices were radical interventions into the dominantly white theatre cultures of the USA and the UK (in the first instance). Both practices were pioneered in the mid-20th-century by New York City director, Joseph Papp in his Shakespeare in the Park productions - notably with James Earl Jones as King Lear in 1973.9 A colour-blind production, in essence, expects actors and audiences to act as if they cannot see racial difference that the play performed is neutral; its underlying biases have been neutralised and, as such, its worldview has been universalised. Colour-blindness, when it emerged in the late 1970s, acted as a strategy for inclusion, an attempt to reset the default relationship between the otherwise very white play world and the not-so-white real world. In university theatres, it was also a necessity as theatre classes became more integrated. (Gender neutral casting, whether cross-dressing or re-gendering roles, arose from similar exigencies.) The socio-political implication is that we're all the same under the skin, and that the plays we perform, like the lives we live, have less to do with race than with our common humanity. 'If you prick us, do we not bleed . . .' as Shakespeare's Jew puts it (Merchant III.i.59-60).

Non-traditional casting is a term that can be seen to encompass colour-blind casting, but its practices and implications are more diverse (so to speak). At its best, it deconstructs and exposes status quo assumptions of race, gender and culture for critique. Consider the ground-breaking premiere of Caryl Churchill's Cloud 9 in 1979, which demonstrated the ways sexism and racism continue to be

\footnotetext{
${ }^{9}$ See Blau, 1979. Of course, Joseph Papp was not the first director to integrate the Shakespearean stage. In fact, in the $19^{\text {th }}$ century, New York City was home to a number of African American theatre companies, all of which had an abiding interest in Shakespeare's plays, and one of the century's most famous Shakespearean actors was Ira Aldridge, an African American whose career spanned the USA, the UK and the world. (See Hill \& Hatch, 2003.)
} 
emmeshed in colonisation and its aftermath by disrupting the conventional identifications of characters with the bodies of the actors playing them. Churchill's original theatre work, advancing from the model provided by Brecht, demanded that audiences engage uneasily in double-seeing: the story told by the dominant culture, the labour by which that story is produced and reproduced, the essential performativity of social identity and the inescapability of our own culpability as participants in systems of oppression. 10

Joseph Papp's approach to Shakespeare was more humanistic, less radically inclined, and it had odd blindspots. The Public Theatre production of A Midsummer Night's Dream that I saw in 1988 was set in Brazil.11 The aristocrats were marked as white, the fairies as black, and the rustics as Hispanic. The roles of Theseus/Oberon and Hippolyta/Titania were (unusually) uncoupled to enforce the (constructed) ethnic differences between the three groups, and non-Hispanic actors with F Murray Abraham in the lead put on Spanish accents to reinforce their lower-class status as the rustics. The production was jolly. The audience loved it. And I continue to be disturbed by what I saw: a reification of race and class differences masked by a celebratory, self-congratulatory performance of inclusivity. So too a production of The Merchant of Venice at London's Globe Theatre in 199812 where somehow the play's intrinsic anti-Semitism was overshadowed, in my view, by the way the black actors playing the sidekicks veered rather too much towards minstrelsy. ${ }^{13}$ I guess we call such things 'unconscious bias' these days, but theatre is about making visible, which to me implies acts that are conscious and meaningful.

More recently, and closer to home, there have been a number of productions of Othello with well-known Māori theatre artist, Jim Moriarty, in the title role, one of which I was

\footnotetext{
10 Cloud 9 was first produced in 1979, the same year Joseph Papp declared: 'I believe in integration, but not assimilation. [. . . ] I love the differences' (qtd in Blau, 1979).

${ }^{11}$ For a fair description of the production, see the New York Times review by Frank Rich (1988).

${ }^{12}$ For production credits, see http://bufvc.ac.uk/shakespeare/index.php/title/av37941.

13 The Pop-up Globe took a run at Merchant of Venice last year; as with other productions I've seen, it demonstrated that the play's anti-

Semitism cannot be effectively countered with sincerity.
} 
fortunate to see in Christchurch at the Court Theatre in 2001.14 There is a certain logic to this casting, a ready transference from the military milieu of Shakespeare's imagination to colonial New Zealand, and from the Moor to the Māori, as can be seen in the proliferation of Othellos featuring Māori actors here. 15 The Court Theatre production did not ask its audience to turn a blind eye to Moriarty's Māori identity. Quite the opposite. It was central to the way the production made meaning, and at the heart of Moriarty's portrayal of the Moor - now Māori - especially as he gave way to his jealous rage, progressing from wiri to haka, and from English to te reo Māori. Moor or Māori, Shakespeare's play strips the soldier of his courtly veneer to reveal the savage within. The violent murder of Desdemona retains its tragic inevitability. Othello's suffering is existential, driven by the impulses deep within his racialised body, and as such inescapable. In witnessing such acts on the Court Theatre's mainstage were we - the majority of us in the audience who were not Māori - to be provoked to think about our complicity in and the consequences of colonisation? Or were we simply, and sentimentally, satisfyingly, supposed to be very sad to watch nature take its course? Further, and more troubling: in showing us an essentialised native Othello - not a white man blacked up so that we could see both the artifice and the social construction of the outsider, but a Māori man as himself - were we who are, most of us, not that not also party to the naturalisation of the otherness of the savage savage?

\section{(De)Colonising Shakespeare?}

The contract between performers and spectators always involves agreements to see certain aspects of a production while overlooking others. Since the early $19^{\text {th }}$ century, following Coleridge, we in the theatre generally understand this to be the well-worn (to the point of fuzziness) 'suspension of disbelief'. When we say 'colour-blind' or 'non-traditional' casting, we don't supersede this agreement so much as add it

\footnotetext{
${ }^{14}$ For the Court Theatre production credits, see the Theatre Aotearoa archive:

http://tadb.otago.ac.nz/Theatre1/Web/WebSearch.php?Session=Gue st-X-568149305.

15 See the list of productions on the Theatre Aotearoa website. Moriarty performed the role also in Wellington in 2007

(https://www.theatreview.org.nz/reviews / production.php?id=424).
} 
to the prescriptions for how we are to see what we are looking at. Watching the Pop-up Globe's bicultural Dream, do we see as we are directed - an authentic post-colonial intervention into Shakespeare's play text?

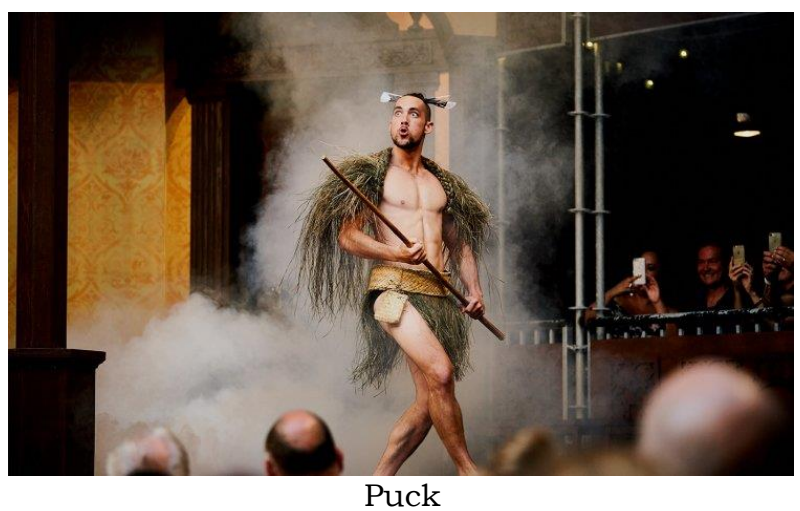

Puck as a Māori warrior? The Forest of Arden as the New Zealand bush during the early days of contact perhaps? The mist of Shakespeare's imagination (and the contemporary smoke machine) not so different from the fog up north? If so, what else might we see? Do we see what the early European settlers might have seen - a mystical, mystifying dreamworld where nature and native alike are there to scare, bewilder and amuse us until dawn breaks and we can return to the 'real' civilised world?

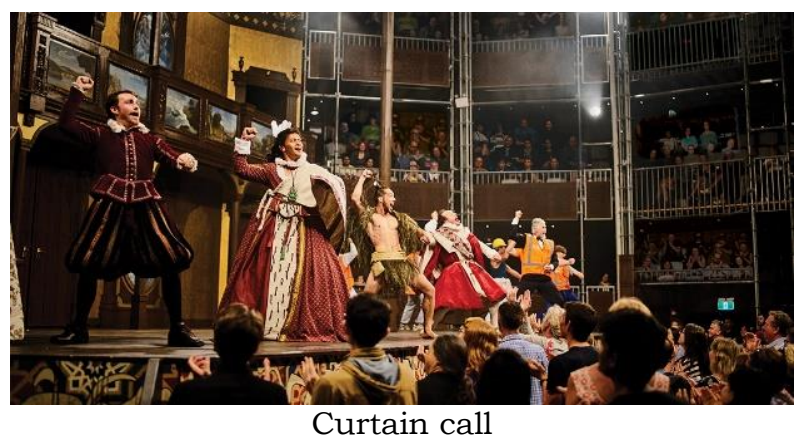


And in the end, what do we perceive? A utopian performative (Dolan, 2005): a post-Elizabethan, post-colonial world in which we have moved past our colonialist history (if we can forget for a moment that there are only men onstage)? A case study in cruel optimism (Berlant, 2011): a dream of post-colonial comity - Brits, Māori and Kiwi blokes at play through the night - from which everyone inevitably awakens to the restoration of the status quo? Or an incitement to social works (Jackson, 2011) yet to be performed? 


\section{References}

Balme, C. (1999). Decolonizing the Stage: Theatrical Syncretism and Post-Colonial Drama. Oxford \& New York: Oxford University Press.

Berlant, L. (2011). Cruel Optimism. Durham, NC: Duke University Press.

Bharucha, R. (1993). Theatre and the World: Performance and the Politics of Culture. London: Routledge.

Blau, E. (1979). Papp Starts a Shakespearean Repertory Troup Made up Entirely of Black and Hispanic Actors. New York Times. Retrieved from:

https://www.nytimes.com/1979/01/21/archives/pappstarts-a-shakespearean-repertory-troupe-made-up-entirelyof.html.

Deboo, A. (1990). The Non-Traditional Casting Project Continues into the '90s. TDR 34(4), pp. 188-191.

Desmarais, F. (2018, July 19). Pop up Globe: Artistic director apologises for using \#metoo in all-male Shakespeare promotion. Retrieved from:

https://www.stuff.co.nz/entertainment/stage-andtheatre/105588840/popup-globe-abuse-of-power-to-usemetoo-in-allmale-shakespeare-promotion.

Dolan, J. (2005). Utopia in Performance: Finding Hope in the Theater. Ann Arbor, MI: University of Michigan Press.

Hill, E. \& Hatch, J. (2003). A History of African American Theatre. Cambridge, UK: Cambridge University Press.

Houlahan, M. (2002). Shakespeare in the Settlers' House. Journal of New Zealand Literature (20), pp. 112-124.

Jackson, S. (2011). Social Works: Performing art, supporting publics. New York: Routledge.

Joseph, D. (2017, December 8). Review: A Midsummer Night's Dream. $N Z$ Herald. Retrieved from: https://www.nzherald.co.nz/entertainment/news/article.cfm? c_id=1501119\%objectid=11956095.

McDougall, J. (2011). Māori take on Shakespeare: The Merchant of Venice in Aotearoa/New Zealand. Multicultural Shakespeare: Translation, Appropriation and Performance 8(23), pp. 93-106.

Newman, H. (1989). Holding Back: The Theatre's Resistance to Non-Traditional Casting. TDR 33(3), pp. 22-36.

Pop-up Globe. (n.d.). A Midsummer Night's Dream. Retrieved from: https://popupglobe.com.au/shows/midsummer-nightsdream/. 
Pop-up Globe. (n.d.). Welcome. Retrieved from: https://popupglobe.co.nz/about/welcome/.

Pop-up Globe. (2018, January 8). Winter Season 3: A Midsummer Night's Dream. YouTube. Retrieved from: https: / www.youtube.com/watch?v=fE2HgT4bj9U.

Rich, F. (1988, January 13). Theater: 'Midsummer Night'. New York Times. Retrieved from: https://www.nytimes.com/1988/01/13/theater/theatermidsummer-night.html.

Rogers, A. \& Thorpe, A. (2014). A Controversial Company: Debating the Casting of the RSC's The Orphan of Zhao. Contemporary Theatre Review 24(4), pp. 428-435.

Schultz, R. (1991). Non-Traditional Casting Update: Multicultural Casting Providing Opportunity for Minority Actors While Stimulating Innovative Productions. TDR 35(2), pp. 7-13.

Shakespeare, W. (2017). The Merchant of Venice. New York: Penguin.

Shakespeare, W. (2005). A Midsummer Night's Dream. London: Penguin.

Thomas, S. (2014). 'The Dog, the Guard, the Horses and the Maid': Diverse Casting at the Royal Shakespeare Company. Contemporary Theatre Review 24(4), pp. 475-485.

Thompson, A. (2011). Passing Strange: Shakespeare, Race, and Contemporary America. Oxford: Oxford University Press.

Young, H. (2013). Theatre and Race. Basingstoke \& New York: Palgrave Macmillan. 